\title{
Legitimacy in a Federal System
}

William R. MacKay ${ }^{i}$

\section{$\underline{\text { Introduction }}$}

Although federalism of various types has existed throughout history, ancient and medieval federations were, on the whole, short-lived. ${ }^{1}$ Most federations were nonexistent by the time of the enlightenment and the rise of nation-states. So-called modern federalism stems from the American republic founded in 1787, which in many ways is the archetypal one, representing the creation of a federal government by compact among several previous constituent units - e pluribus unum. The federalist structure is becoming increasingly popular as 90 percent of states today contain a plurality of national, ethnic or linguistic groups. ${ }^{2}$ Nevertheless, a normative theory of federalism has not been fully developed. ${ }^{3}$ Indeed, Wayne Norman notes that in the history of modern political philosophy, questions of federalism have generally attracted no more than a footnote or a chapter, although cursory discussion can be found in the writings of such luminaries as J.S. Mill, Bodin, Grotius, Montesquieu, Bentham, Constant and Sidgwick. ${ }^{4}$ Such a theory will aid in setting standards with which we can we assess, evaluate, justify, defend or attack the structure and operation of the federal system. Although I do not attempt in this paper to elucidate a complete theory of federalism through a normative lens, I will attempt to demonstrate one of the primary means by which citizens in a federal state (in particular, Canada) evaluate the legitimacy of government action.

\section{$\underline{\text { Legitimacy as Consent }}$}

\section{a. Legitimacy Beyond the Rule of Law}

According to William Connolly ${ }^{5}$, Max Weber's definition of legitimacy provides the starting point for any contemporary discussion of legitimacy. Weber concludes there are three alternative claims to legitimacy: traditional, charismatic, and legal. ${ }^{6}$ Legitimacy may reside in an appeal to tradition or the established belief in the sanctity of long-

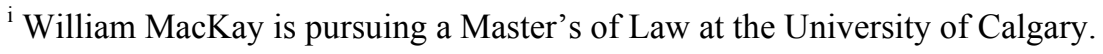


established traditions and the legitimacy of those exercising authority under them. Legitimacy may equally be founded on charisma. This is the devotion to the exceptional sanctity, heroism or exemplary character of an individual person and the "normative patterns of order revealed or ordained by him" "7. Finally, a claim might appeal to rational procedures or a belief in the legality of enacted rules and the right of those elevated to authority under such rules to issue commands. In a liberal democracy, legitimacy of governmental action is judged primarily on legal terms. At a minimum, legitimacy entails government action that is consistent with the rule of law. The rule of law requires citizens to be subject to known legal rules and executive accountability to the legal authority. ${ }^{8}$ However, even among committed legal positivists, the normative forms of the modern legal order go beyond mere legislation. ${ }^{9}$ Legitimacy in the broader sense must demonstrate some form of consent to authority. Central to this normative evaluation of law as consent is both a rights evaluation and a contractualist one.

\section{b. Legitimacy as Action Consistent with Legal Rights}

Rights theory is based on the belief that certain natural rights are inviolable. ${ }^{10}$ The theory is premised on the belief that an immoral law is no law at all. ${ }^{11}$ In the modern sense, according to Hohfeld's widely accepted definition, a right is a legal claim that can be asserted against others, including, where relevant, the prevailing governmental power. ${ }^{12}$ Rights holders may act as they choose within the scope of the right, regardless of the practical result. Further, many liberal democratic states today have a written Bill of Rights which set out certain inviolable rights that cannot be infringed by government action. Thus, even though laws are passed in accordance with the Diceyan ${ }^{13}$ conception of the rule of law, they cannot be valid if they breach fundamental rights outlined in a written Bill of Rights.

\section{c. Legitimacy as Action Consistent with Contract}

Contractual theory has its roots in Thomas Hobbes ${ }^{14}$ and Jean Jacques Rousseau ${ }^{15}$. Locke expressed it as: 
Men being, as has been said, by nature all free, equal, and independent, no one can be put out of this estate and subjected to the political power of another without his consent. The only way whereby any one divests himself of his natural liberty and puts on the bonds of civil society is by agreeing with other men to join and unite into a community for their comfortable, safe, and peaceable living one amongst another, in a secure enjoyment of their properties and a greater security against any that are not of it. ${ }^{16}$

Thus, according to contractual theory, government is a compact entered into by the people acting in their own self-interest for self-preservation. As the people have freely consented to authority, consent is the primary means of determining the legitimacy of governmental action. The idea of consent was used as a legitimizing principle most recently by John Rawls. ${ }^{17}$ For Rawls, consensus around a liberal conception of justice is the only viable basis for a stable union in modern democratic societies, which are characterized by what he calls the "fact of pluralism". As citizens have, and will continue to have, competing comprehensive moral conceptions that involve different convictions about what makes life valuable, and what moral theories ground such beliefs, a common consensus must be reached for liberal democracy to remain viable.

Like Max Weber, Rawls saw three possible bases of social union (or basis of consent to authority). First, there could be universal acceptance of some particular comprehensive moral doctrine. Rawls sees this as unrealistic given the pluralistic nature of the modern liberal democratic state. Second is self-interest. Like Hobbes, Rawls saw a possible basis of legitimacy to be a pragmatic one in which citizens submit to authority and social union on the basis of need. However, Rawls rejects this as too temporary in nature. Once the conditions that brought on the consent shift, the legitimacy of the authority will be questioned. The third basis of consent Rawls recognizes is the overlapping consensus around a political conception of justice. This will be a narrow enough conception of the good to ensure the long-term viability of the legitimacy of authority and is less prone to desertion when it is to one party's advantage.

\section{Consent in a Federal System}

\section{d. Justifications for Federalism}


Richard Simeon lists the justifications for federal governance as: effectiveness, community, and democracy. ${ }^{18}$ Effectiveness justifies an action by a constituent or national level of government where it will enhance the capacity of government institutions to generate effective policy and respond to citizen needs. The principle of community justifies the exercise of authority from the level of government that best represents the community affected. Moreover, it will appeal to the image of the ideal or preferred community that that constituency represents. Finally, the democracy justification is used to attempt to legitimize federal or provincial actions by demonstrating that the exercise of power by that level of government promotes democracy. A national government will appeal to majority support in the nation-state as a whole to justify its authority. A state or provincial government, on the other hand, will try to demonstrate that its legitimacy to oppose national authority is based on a majority within its borders opposed to the imposition of federal authority and maintain that federal action is an illegitimate use of federal power because it will be a manifestation of the tyranny of the majority federalism is intended to prevent. ${ }^{19}$

\section{e. Federal Sub-Units as Political Communities}

In a federal system, authority will only be considered legitimate if citizens accept it on the basis of both a traditional appeal to legitimacy and a corollary federal value. The justification I will be focusing on is community, which is particularly relevant to the Canadian federal system. ${ }^{20}$ The legitimacy of federal action is therefore assessed in its ability to successfully maintain a balance between the provincial and national communities.

This is a broader conception than nationalism. Essentially, our community determines who we are; it is the context in which we exist and which gives meaning to our actions. ${ }^{21}$ Communitarian arguments reject the idea that individuals are an aggregation of identifiable preferences that exist prior to, or apart from, any group. Instead, citizens form preferences with reference to that community as well as by 
traditional modes of political action. Political philosophers from Aristotle to Montesquieu insisted that political units had to stay relatively small, because only a small polity could possess sufficient social and moral commonality to be self-governing. ${ }^{22}$ This is a common reason for adopting a federal system. Although James Madison argued that a large national government could more effectively control the tendency toward faction in popular governments ${ }^{23}$, he also insisted that the jurisdiction of the central government be limited, with states and localities retaining control over matters within their traditional authority. ${ }^{24}$ Madison assumed that a large and diverse nation could not offer the same sense of moral community as a small and relatively homogeneous republic. ${ }^{25}$

In Canada, provinces are for the most part what have been called political communities. These have aspects of affective communities, which consist of mutual attachments through personal contact and day-to-day relationships. ${ }^{26}$ Further, they are also dialogic communities, which emphasize the instrumental role of public debate and uncoerced persuasion in arriving at collective decision-making (i.e. legitimate decision making). ${ }^{27}$

These values are particularly connected in federations based on national cleavages. However, the values may also be based on traditional ways of life or economic structure that create differences among otherwise homogenous federal states. For example, the American Civil War was largely fought to bring the southern states back into the union. The Confederacy saw secession as the only means to preserve its traditional plantation economy in the face of a federal government seemingly dedicated to destroying its economic base. Similarly, the imposition of the federal National Energy Policy in Canada by the federal government was seen as an attack by the provincial political community on the traditional resource economy of Alberta and thereby viewed as illegitimate despite its constitutional validity.

Specifically, both of these federal actions were viewed by the citizens of the respective state and provincial governments as a breach of the self-determination inherent in the federal value of community. Both situations were an affront to what the people 
thought was the federal principle that allows the government closest to them to make decisions about particular local issues. In these cases, the resource economy and the cotton economy were deemed to be essential to the communities and particular to the region. As such, the citizens believed the only legitimate use of power was by the constituent government itself, or at least with their consultation.

Thus, democratic claims to legitimacy in a federal system are often linked to similar traditional legal claims to legitimacy. This legitimacy depends on using mechanisms which are consistent both with federal democratic values, in that they are constitutionally valid and, in a broader sense, are not a manifestation of the tyranny of the majority over a discrete political community. As a final example, I would point to the imposition of the Charter of Rights in Canada. Legally, the federal government was in a position to patriate the new Constitution Act, $1982^{28}$ (which included the Charter of Rights) absent any provincial consent. ${ }^{29}$ The Charter was eventually adopted with the approval of all provinces except Quebec. Indeed, to this day all laws passed in Quebec are passed "notwithstanding" of authority.

However, it could not be said that the people of Quebec did not accept the principles of the Charter. Nor do Quebeckers see the imposition of the Charter as illegal. Nevertheless, the Charter is deemed illegitimate by Quebeckers because it is perceived to have been imposed by the federal government on the people of Quebec in spite of the opposition of the provincial government, an illegitimate use of authority because it is a breach of the federalist goal of protecting political communities. ${ }^{31}$

A federal system is one of dual sovereignty. Both the federal and regional governments are sovereign in its sphere of governance and should be independent of one another. ${ }^{32}$ Thus, at its core, the federal system can be understood as the integration of political communities that share a common population. The legitimacy of federal action is therefore assessed by its ability to successfully maintain a balance between the provincial and national communities. Thomas Franck made a similar determination: ${ }^{33}$ 
While most literature about the social contract addresses the formation of a community by persons, contractarian theory is also readily applicable to, and influential in, the evolution of a community of states.

Franck demonstrates the community's impact on citizens' understanding of legitimacy with this remark: ${ }^{34}$

It is only by reference to a community's evolving standards of what constitutes right process that it is possible to assert meaningfully that a law, or an executive order, or a court's judgment, or a citizen's claim on a compatriot, or a government's claim on a citizen is legitimate.

\section{f. The Rights of Political Communities}

In federalist theory, particularly in the United States, the partial independence of the two levels of government is usually defined in terms of rights. The point is to allow normative disagreement amongst the subordinate units so that different units can subscribe to different value systems. ${ }^{35}$ In a similar manner to citizens, sub-units in a federal state may act as they choose within the scope of the right, regardless of the practical result. When the larger nation state acts within the scope of the sub-unit's rights to obtain the results it desires, that right is abrogated. The constitution defines and guards the rights of the sub-units with an arbiter designated as the ultimate determiner of whether rights were violated. For example, in Gregory v. Ashcroft ${ }^{36}$ Madam Justice O'Connor, writing for the majority, stated in reviewing legislation the Court was required to declare legislation ultra vires where the division of powers in the Constitution compelled it to do so even if "one could prove that federalism secured no advantages to anyone." 37

\section{g. The Federal Contract}

Contractual theory forms the basis of much of the current understanding of federalist relations. The federal framework is recognized as having the nature of a state 
system safeguarded by an effective coercive apparatus such as the federal Constitution. It is rigorously understood as a contract, generating the members' consensus as the base of the system. ${ }^{38}$ The American Senator John C. Calhoon stated: ${ }^{39}$

...the present constitution is the act of States themselves, which is the same thing as the people of the several States, and forms a union of them as sovereign communities...the confederation was a contract between agents-the present Constitution a contract between the principals themselves.

Similarly, Kant in Perpetual Peace $(1795)^{40}$ envisioned a pact between nations binding each and every one of them to certain rules in order to overcome the defects generated by state sovereignty. According to Kant, nations make war because they find themselves in a state of nature and the transition to political society, which worked for people within individual countries, must be extended to nations. Finally, Wayne Norman uses this approach as well and recommends that federal principles and institutions be judged as if they were selected by enlightened federal partners interested in developing a stable, mutually beneficial federation in the long-term. Norman's theory, like modern contractual theories applying to unitary states and their citizens, maintains that it is irrelevant in the first instance whether there actually was a contract but when evaluating the institutions we must look at historical pacts, treaties and traditions. The task, according to Norman, is to sketch the basic normative structure starting from the situation of independent nations negotiating to form a just and stable federation. Applying such a general theory to an actual federation will involve balancing its recommendations with the moral force of historical arguments. ${ }^{41}$

The consensus can be built, at a minimum, on what is an unjust federation. Norman includes in this: the perception by the citizens of any sub-unit that it is unfairly disadvantaged in the federation or that it is underrepresented in key federal institutions; mutual lack of understanding among citizens and political elites of different regions or provinces of each others' political, economic, or cultural situation; divergent perceptions of the history or prehistory of the federation; mutual distrust concerning the use of federal institutions; resentment by one minority represented as a majority in a sub-unit concerning the treatment of its people. ${ }^{42}$ 
The way to avoid the perception of an unjust federation is to base it on the normative quality of trust. ${ }^{43}$ According to Daniel Weinstock, the central government can encourage trust among the members and representatives of groups assembled within the same society at the national level. Citizens of sub-units must not perceive that the federal government is posing threats to the interests that distinguish them from the nation as a whole. Through the federalist system, groups will generate a common political identity that will foster the achievement of social values and goals traditionally identified with societies that have a strong common national identity.

\section{Conclusion}

Essentially, the subject of a federal state is what David Held calls the "cosmopolitan" citizen. ${ }^{44}$ Held, posits that the citizen in the modern liberal-democratic state has several allegiances to various actors. Included in this, I would submit, is the sub-unit the citizen happens to live in. This is particularly the case in some provinces of Canada. There is a national community (those who hold primary allegiance to the Canadian state) and separate provincial communities (those who hold primary allegiance to their province). However, the degree of bifurcation varies from province to province. Nevertheless, in Canada, all provinces have significant provincial communities except Ontario. $^{45}$

It is my assertion that the cosmopolitan citizen has always existed in federal states with allegiances to the federal or constituent government fluctuating based on his or her understanding of the value of federalism generally and the specific federal values of his or her broader nation-state. Accordingly, government action in a federal state will only be legitimate if it successfully appeals to two notions. First, citizens must accept government authority on the basis of traditional Weberian notions of legal legitimacy. In

a federal state this means that the action must be consistent with the government's constitutionally defined rights. Second, authority must be legitimate in that it does not undermine the political communities fostered by federalism. 
Therefore, at a minimum, legitimacy of governmental action in a federal system must be consistent with the federal contract. The contract is based on the mutual consent of the constituent units to legislative or executive action by the federal government. This consent will be determined primarily by a contractual interpretation of the historic reading of the federal constitution. However, where the legal interpretation is unclear, the political communities within the federal system must not have a sense that action is being imposed on them illegitimately, in that it is without their consent. Where this occurs, the trust in the federation of the constituent political community will be undermined and the long-term viability of the federation compromised.

\footnotetext{
$\underline{\text { Notes }}$

${ }^{1}$ W.H. Riker, Federalism: Origin, Operation, Significance, (Boston: Little, Brown \& Company, 1964) 5.

${ }^{2}$ W.J. Norman, “Towards a Philosophy of Federalism”, Group Rights, ed. J. Baker (Toronto: University of Toronto Press, 1994) 83.

${ }^{3}$ See D. Weinstock, "Toward a Normative Theory of Federalism", Forum of Federations Documents at 1, www.ciff.on.ca; W.J. Norman, supra note 2 at 82; R. E. Simeon, "Criteria for Choice in Federal Systems." Queen's Law Journal 8 (1982): 132.

${ }^{4}$ See Norman, supra note 2 at 97.

${ }^{5}$ W. Connolly, "Legitimacy and Modernity", Legitimacy and the State, ed.W. Connolly (Oxford: Basil Blackwell, 1984) 8.

${ }^{6}$ M. Weber, "Legitimacy, Politics and the State", in Connolly, supra note 1 at 34.

${ }^{7}$ M. Weber, Economy and Society, vol. 1 (Berkeley: University of California Press, 1978) 215. [As cited in Connolly, supra note 1].

${ }^{8}$ Re: Manitoba Language Rights, [1985] 1 S.C.R. 721 at 730.

${ }^{9}$ Murphy and Coleman, Philosophy of Law (Boulder: Westview, 1990) 69.

${ }^{10}$ For an example, see Locke, The Second Treatise of Government, ed. T. P. Peardon (New York: Macmillan, 1952) 79.

${ }^{11}$ For an example, see St. Thomas Aquinas, "Summa Theologica, [First Part of the Second Part]" The Essence of Law, as reproduced in D. Bigongiari, The Political Ideas of St. Thomas Aquinas (New York: Hafner Press, 1953) 7.
} 
${ }^{12}$ J. Singer, "The Legal Rights Debate in Analytical Jurisprudence from Bentham to Hohfeld." Wisc. Law Rev. (1982): 986.

${ }^{13}$ A.V. Dicey, Introduction to the Study of Law of the Constitution (London: McMillian, 1975) 199.

${ }^{14}$ T. Hobbes, Leviathan (London: Penguin Classics, 1968) 236.

${ }^{15}$ J.J. Rousseau, The Social Contract (London: Penguin Classics, 1968) 59.

${ }^{16}$ Locke, supra note 10 at 54.

${ }^{17}$ J. Rawls, "The Idea of an Overlapping Consensus." Oxford Journal of Legal Studies 7 (1987): 1.

${ }^{18} \mathrm{R}$. Simeon, supra note 3.

${ }^{19}$ For an example, see Hamilton, Jay, Madison, The Federalist Papers, Federalist No. 10 (New York: New American Library, 1961) [see esp. Federalist Paper No. 39].

${ }^{20}$ Simeon, supra note 3 at 135-136.

${ }^{21}$ M. J. Sandel, Liberalism and the Limits of Justice as cited by E. L. Rubin \& M. Feeley, "Federalism: Some Notes on a National Neurosis" U.C.L.A. Law Review 41 (1994): 936

${ }^{22}$ W. M. McClay “The Soul of Man Under Federalism.” First Things 64 (1996): 23.

${ }^{23}$ Madison, supra note 19 at 77.

${ }^{24} \mathrm{Ibid}$ at 291.

${ }^{25}$ Ibid at 290.

${ }^{26}$ Rubin, supra note 24 at 936.

${ }^{27}$ J. Habbermas, The Theory of Communicative Action (Thomas McCarthy trans., 1984) 273-337. [as cited by Rubin, supra note 21 at 938].

${ }^{28}$ U.K, 1982, c. 11.

${ }^{29}$ Re: Resolution to Amend the Constitution, [1981] 1 S.C.R. 753 affirmed the legal principle that the constitution could be amended absent any provincial consent.

However, the court noted that tradition dictated that substantial provincial consent was necessary to amend.

${ }^{30}$ S. 33 (the notwithstanding clause) of the Charter allows a province to opt out of the provisions of the Charter for a period up to five years.

${ }^{31}$ G. Laforest, Trudeau and the End of a Canadian Dream (Montreal: McGill-Queen's University Press, 1995) 149.

${ }^{32}$ K.C. Wheare, Federal Government $\left(4^{\text {th }}\right.$ ed.), (Oxford: Oxford University Press, 1963$)$ 14.

${ }^{33}$ T. Franck, Fairness in International Law and Institutions (Oxford: Oxford University Press, 1995) 26-27.

${ }^{34}$ Ibid at 26.

${ }^{35}$ E. L. Rubin, supra note 21 at 912.

${ }^{36}$ (1992), 112 S. Ct. 2408.

${ }^{37} \mathrm{Ibid}$ at 2417-23 as cited in E. L. Rubin, supra note 21 at 906.

${ }^{38}$ A. La Pergola, Residui "Contrattualistici" e Struttura Federale nell' Ordinamento degli Stati Uniti (Milan: Giuffre, 1969) at 92) as cited by L. M. Bassani, "Jefferson, Calhoun and State's Rights: the Uneasy Europeanization of American Politics", (1999), 114 Telos 132. at 136.

${ }^{39}$ The Papers of John C. Calhoon, ed. C.N. Wilson (Columbia: South Carolina University Press, 1979) Vol. XII; 21. [as cited by Bassani, ibid at 149]. 
${ }^{40}$ I. Kant, Perpetual Peace (Adelaide: University of Adelaide e-tests, 1999); http://www.arts.adilaide.edu.au/personal/Dhart?eTexts/Enlightenment/Kant/PerpetualPea ce1795.html

${ }^{41}$ Norman, supra note 2 at 85.

${ }^{42}$ Ibid at 96.

${ }^{43}$ Weinstock, supra note 3.

${ }^{44}$ D. Held, "The changing contours of political community", Global Democracy: Key Debates, ed. Barry Holden (Routlege: London, 2000).

${ }^{45}$ See R. Gibbins, "Regional Politics", Politics: Canada (Toronto: McGraw Hill Ryerson, 1987) 196 where the author notes that surveys reveal that for Canada as a whole, $74 \%$ choose Canada as there first loyalty and $26 \%$ their province. Ontario was at the low end with only $5 \%$ identifying with their province and Newfoundland had the highest provincial identification at $58 \%$.

\section{Bibliography}

St. Thomas Aquinas, Summa Theologica [First Part of the Second Part] The Essence of Law, as reproduced in D. Bigongiari, The Political Ideas of St. Thomas Aquinas, (New York: Hafner Press, 1953).

L. M. Bassani, “Jefferson, Calhoun and State's Rights: the Uneasy Europeanization of American Politics.” Telos 114 (1999): 132.

W. Connolly (ed.), Legitimacy and the State (Oxford: Basil Blackwell, 1984).

Constitution Act, 1982, U.K, 1982, c. 11.

A.V. Dicey, Introduction to the Study of Law of the Constitution (London: McMillian, 1975).

T. Franck, Fairness in International Law and Institutions (Oxford: Oxford University Press, 1995).

R. Gibbins, "Regional Politics", Politics: Canada (Toronto: McGraw Hill Ryerson, 1987).

Gregory v. Ashcroft (1992), 112 S. Ct. 2408.

Hamilton, Jay, Madison, The Federalist Papers, Federalist No. 10 (New York: New American Library, 1961) 
D. Held, "The changing contours of political community", Global Democracy: Key

Debates ed. Barry Holden (Routlege: London, 2000).

T. Hobbes, Leviathan (London: Penguin Classics, 1968).

I. Kant, Perpetual Peace (Adelaide: University of Adelaide e-tests, 1999); http://www.arts.adilaide.edu.au/personal/Dhart?eTexts/Enlightenment/Kant/PerpetualPea ce1795.html

G. Laforest, Trudeau and the End of a Canadian Dream (Montreal: McGill-Queen's University Press, 1995).

Locke, The Second Treatise of Government ed. T. P. Peardon (New York: Macmillan, 1952).

Re: Manitoba Language Rights, [1985] 1 S.C.R. 721.

W. M. McClay “The Soul of Man Under Federalism.” First Things 64 (1996): 21.

Murphy and Coleman, Philosophy of Law (Boulder: Westview, 1990).

W.J. Norman, “Towards a Philosophy of Federalism” Group Rights ed. J. Baker (Toronto: University of Toronto Press, 1994) 79.

J. Rawls, "The Idea of an Overlapping Consensus." Oxford Journal of Legal Studies 7:1 (1987): 1 .

Re: Resolution to Amend the Constitution, [1981] 1 S.C.R. 753.

W.H. Riker, Federalism: Origin, Operation, Significance (Boston: Little, Brown \& Company, 1964).

J.J. Rousseau, The Social Contract (London: Penguin Classics, 1968).

E. L. Rubin \& M. Feeley, "Federalism: Some Notes on a National Neurosis." U.C.L.A. Law Review 41 (1994): 904.

R. E. Simeon, “Criteria for Choice in Federal Systems.” Queen's Law Journal 8 (1982): 131.

J. Singer, "The Legal Rights Debate in Analytical Jurisprudence from Bentham to Hohfeld." Wisc. Law Rev. (1982): 975.

D. Weinstock, "Toward a Normative Theory of Federalism", Forum of Federations Documents, www.ciff.on.ca; 
